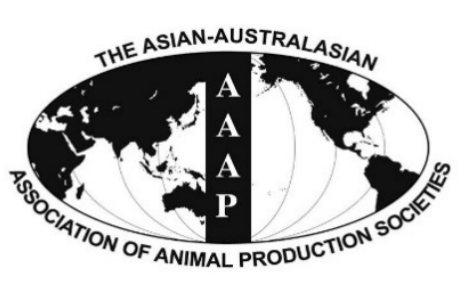

Open Access

Asian Australas. J. Anim. Sci.

Vol. 29, No. 4 : 523-529 April 2016

http://dx.doi.org/10.5713/ajas.15.0358

www.ajas.info

pISSN 1011-2367 elSSN 1976-5517

\title{
Effects of Rice Straw Supplemented with Urea and Molasses on Intermediary Metabolism of Plasma Glucose and Leucine in Sheep
}

\author{
Mohammad Khairul Alam, Yasumichi Ogata, Yukari Sato, and Hiroaki Sano* \\ Department of Animal Sciences, Faculty of Agriculture, Iwate University, Morioka 020-8550, Japan
}

\begin{abstract}
An isotope dilution method using $\left[\mathrm{U}-{ }^{13} \mathrm{C}\right]$ glucose and $\left[1-{ }^{13} \mathrm{C}\right]$ leucine (Leu) was conducted to evaluate the effects of rice straw supplemented with urea and molasses (RSUM-diet) on plasma glucose and Leu turnover rates in sheep. Nitrogen (N) balance, rumen fermentation characteristics and blood metabolite concentrations were also determined. Four sheep were fed either mixed hay (MH-diet), or a RSUM-diet with a crossover design for two 21 days period. Feed allowance was computed on the basis of metabolizable energy at maintenance level. The isotope dilution method was performed as the primed-continuous infusion on day 21 of each dietary period. Nitrogen intake was lower $(p=0.01)$ for the RSUM-diet and $\mathrm{N}$ digestibility did not differ $(p=0.57)$ between diets. Concentrations of rumen total volatile fatty acids tended to be higher $(\mathrm{p}=0.09)$ for the RSUM-diet than the MH-diet. Acetate concentration in the rumen did not differ $(\mathrm{p}=0.38)$ between diets, whereas propionate concentration was higher $(\mathrm{p}=0.01)$ for the RSUM-diet compared to the MH-diet. Turnover rates as well as concentrations of plasma glucose and Leu did not differ between diets. It can be concluded that kinetics of plasma glucose and Leu metabolism were comparable between the RSUM-diet and the MH-diet, and rumen fermentation characteristics were improved in sheep fed the RSUM-diet compared to the MH-diet. (Key Words: Intermediary Metabolism, Molasses, Rice Straw, Sheep, Stable Isotope, Urea)
\end{abstract}

\section{INTRODUCTION}

The economic point of view and sustainable environmental concerns encourage investigating the possibility of using the crop residue as animal feed. Rice straw is abundantly available crop residues in most tropical and sub-tropical countries and commonly used as a diet for ruminants, although it is low crude protein (CP) content and fermented poorly in the rumen (Alam et. al., 2010; Sarnklong et al., 2010). Supplementation of nitrogenous substrates to rice straw is reported to recover its $\mathrm{CP}$ deficiency and improve its digestibility through providing necessary ammonia $\left(\mathrm{NH}_{3}\right)$ for rumen microbial activities which is essential for better rumen fermentation characteristics (Wanapat et al., 2009). It was also reported that supplementation of nitrogen (N) sources in combination with energy substrates to straw diets improved

\footnotetext{
* Corresponding Author: Hiroaki Sano. Tel: +81-19-621-6165, Fax: +81-19-621-6165, E-mail: sano@iwate-u.ac.jp Submitted Apr. 24, 2015; Revised Jun. 29, 2015; Accepted Aug. 12, 2015
}

feed intake, digestive function along with ruminal characteristics in ruminants through influencing rumen microbial growth (Rooke and Armstrong, 1989; Can et al., 2004; Wu et al., 2005). In most of the tropical countries it is a common practice to use urea and molasses as the sources of $\mathrm{N}$ and soluble carbohydrate, which provide required $\mathrm{NH}_{3}$ and energy substrates for rumen microbial activities (Toppo et al., 1997; Tedeschi et al., 2002; Zinn et al., 2003). However, the effect of rice straw supplemented with urea and molasses (RSUM-diet) on intermediary metabolism of plasma nutrient kinetics in ruminant is scanty.

Glucose is an important energy source for the brain and body tissues and it is particularly important for growth and lactation. Leucine (Leu) is an essential amino acid and requirements of it in ruminants are met from microbes grown in the rumen. It could be expected that the RSUMdiet might influence plasma glucose and Leu metabolism in sheep through providing required $\mathrm{NH}_{3}$ and energy for rumen microbial activities to increase the dietary carbohydrate fermentation. Therefore, the present study was designed to evaluate the effect of the RSUM-diet on turnover rates (TR) 
of plasma glucose and Leu using the isotope dilution methods along with the determination of $\mathrm{N}$ balances rumen characteristics and blood metabolite concentrations in sheep.

\section{MATERIALS AND METHODS}

\section{Animals, diets and management}

Experimental procedures including animal cares, cannulation and blood sampling were reviewed and approved by the Animal Care Committee of Iwate University. Four sound healthy crossbred (Corriedalex Suffolk) shorn sheep (Ovis aries) weighing $46.6 \pm 2.2 \mathrm{~kg}$ of body weight (BW) were used. Two dietary treatments were tested; one was mixed hay (MH-diet) of orchardgrass (Dactylis glomerata) and reed canarygrass (Phalaris arundinacea), other was rice straw (Oryza sativa) supplemented with urea and dried molasses. Feed allowance was computed on the basis of maintenance level metabolizable energy (ME). Chemical composition of experimental feed is shown in Table 1. The ME was assumed $1.73 \mathrm{kcal} / \mathrm{g}$ for mixed hay (NRC, 1985); 1.30 $\mathrm{kcal} / \mathrm{g}$ for rice straw and $2.62 \mathrm{kcal} / \mathrm{g}$ for molasses (NARO, 2006). Feed allowance was mixed hay $57.8 \mathrm{~g} / \mathrm{kg}^{0.75} / \mathrm{d}$ for the MH-diet and rice straw $59.7 \mathrm{~g} / \mathrm{kg}^{0.75} / \mathrm{d}$ supplemented with urea $0.84 \mathrm{~g} / \mathrm{kg}^{0.75} / \mathrm{d}$ and molasses $7.6 \mathrm{~g} / \mathrm{kg}^{0.75} / \mathrm{d}$ for the RSUM-diet. Crude protein supply was given for both diets on dry matter (DM) basis. Urea and molasses were mixed and given on chopped ( 3 to $4 \mathrm{~cm}$ ) rice straw immediately before feeding. Feed was given twice a day at 08:00 $\mathrm{h}$ and 20:00 $\mathrm{h}$ and fresh drinking water was available ad libitum. The experiment was performed using crossover design with two 21 days period. Two sheep were fed the MH-diet during the first period and then the RSUM-diet during the second period, and the other two sheep were fed in the reverse order. The sheep were housed in individual pens in an animal barn during the adjustment period (first two weeks), and on day 15 , the sheep were moved to a controlled house at an air temperature of $23^{\circ} \mathrm{C} \pm 1^{\circ} \mathrm{C}$ with lighting from $8: 00 \mathrm{~h}$ to $22: 00 \mathrm{~h}$ and maintained in wooden metabolism stalls designed for total collection of feces and urine. The sheep were weighed on day of starting the experiment and every 7

Table 1. Chemical composition of experimental feed and supplements on air dry matter (ADM) basis

\begin{tabular}{lcccc}
\hline Item (\%) & Mixed hay & Rice straw & Molasses & Urea \\
\hline Dry matter & 93.3 & 94.7 & 84.6 & ND \\
Crude protein & 12.0 & 4.6 & 12.4 & 288 \\
Crude ash & 10.8 & 14.4 & 12.5 & ND \\
Crude fiber & 28.6 & 31.9 & 8.6 & ND \\
NDF & 68.8 & 73.1 & 30.0 & ND \\
ADF & 32.7 & 41.7 & 20.6 & ND \\
ADL & 2.0 & 2.4 & 5.4 & ND \\
\hline
\end{tabular}

ND, not determined; NDF, neutral detergent fiber; ADF, acid detergent fiber; ADL, acid detergent lignin. days intervals of each dietary period. All experimental procedures were carried out without noticeable stress to the animals.

\section{Nitrogen balance}

Nitrogen balance trial was conducted for 5 days (from day 16 to day 20) of each dietary period as described previously (Alam et al., 2010). Total fecal output was collected daily from each sheep before night feeding. Feces were dried at $60^{\circ} \mathrm{C}$ in a forced air oven for $48 \mathrm{~h}$ and placed at room temperature for 5 days. Then the air dried samples were weighed for measuring the moisture contents and subsamples were ground to pass through a $1 \mathrm{~mm}$ screen, kept them into plastic container and stored at room temperature until analysis. Urine was collected from each sheep every $24 \mathrm{~h}$ in a plastic bucket containing $50 \mathrm{~mL}$ of $6 \mathrm{~N} \mathrm{H}_{2} \mathrm{SO}_{4}$ solution to prevent the escape of $\mathrm{NH}_{3}$. Total volume of daily urine output was recorded by measuring cylinder, then the urine was shaken properly and sub-samples $(50 \mathrm{~mL})$ were stored at $-30^{\circ} \mathrm{C}$ until analysis.

\section{Collection of rumen fluid}

Rumen fluid was collected from each sheep at $2 \mathrm{~h}$ after feeding with orally inserted stomach tube on day 20 of each dietary period. The $\mathrm{pH}$ value was measured by a $\mathrm{pH}$-meter (HM-10P, Toa Electronics Ltd., Tokyo, Japan) immediately after collection of rumen fluid. A sub-sample was centrifuged at $8,000 \times g$ for $10 \mathrm{~min}$ at $2^{\circ} \mathrm{C}$ (RS-18 IV, Tomy, Tokyo, Japan) and then an aliquot of $1 \mathrm{~mL}$ supernatant was acidified by $1 \mathrm{~mL}$ of $0.1 \mathrm{~N} \mathrm{HCl}$ for measuring the rumen $\mathrm{NH}_{3}$ concentration. Finally the prepared samples and residual of rumen fluid were kept frozen at $-30^{\circ} \mathrm{C}$ for later analysis.

\section{Isotope dilution method}

Isotope dilution methods using $\left[\mathrm{U}^{13} \mathrm{C}\right]$ glucose and $[1-$ $\left.{ }^{13} \mathrm{C}\right]$ Leu were conducted to determine the TR of plasma glucose and Leu on day 21 of each dietary period. Two catheters, one for isotope infusion and another for blood sampling were inserted into the left and right jugular veins on the morning of each isotope dilution method. The catheters were filled with sterile solution of tri-sodium citrate $(0.13 \mathrm{~mol} \mathrm{Nacl} / \mathrm{L})$. At 12:00 h, $3.2 \mu \mathrm{mol} / \mathrm{kg}^{0.75}$ of [U${ }^{13} \mathrm{C}$ ]glucose (D-glucose- ${ }^{13} \mathrm{C}_{6}, 99$ atom\% excess ${ }^{13} \mathrm{C}$; Cambridge Isotope Laboratories, Tewksbury, MA, USA) and $7.2 \mu \mathrm{mol} / \mathrm{kg}^{0.75}$ of $\left[1-{ }^{13} \mathrm{C}\right]$ Leu (L-leucine-11- ${ }^{13} \mathrm{C}, 99$ atom $\%$ excess, ${ }^{13} \mathrm{C}$; Cambridge Isotope Laboratories, USA) dissolved in saline solution $(9 \mathrm{~g} / \mathrm{L})$ were injected as priming dose injection through the jugular infusion catheter. Immediately after the priming dose injection, [U$\left.{ }^{13} \mathrm{C}\right]$ glucose and $\left[1-{ }^{13} \mathrm{C}\right]$ Leu were continuously infused at rates of 3.2 and $7.2 \mu \mathrm{mol} / \mathrm{kg}^{0.75} / \mathrm{h}$, respectively, for $4 \mathrm{~h}$ through a multichannel peristaltic pump (AC-2120, Atto Co. 
Ltd., Tokyo, Japan). Blood samples were collected through the sampling catheter immediately before the priming dose injection $(10 \mathrm{~mL})$ and every $30 \mathrm{~min}$ intervals $(5 \mathrm{~mL})$ over the last $2 \mathrm{~h}$ of the primed-continuous infusion of [U$\left.{ }^{13} \mathrm{C}\right]$ glucose and $\left[1-{ }^{13} \mathrm{C}\right]$ Leu. The collected blood samples were transferred to the heparinized tubes and stored in crushed ice until centrifugation. Blood samples were centrifuged at $10,000 \times g$ for $10 \mathrm{~min}$ at $2^{\circ} \mathrm{C}$ and the plasma samples were then stored at $-30^{\circ} \mathrm{C}$ for further analysis.

\section{Chemical analysis}

Dry matter, CP and crude ash contents of the experimental diets were measured according to AOAC (1995). Nitrogen contents in diets, feces, urine and feed refusals were analyzed by Kjeldahl method with the Foss Keltech System (Tecator Digester System and Kjeltec 2300, Foss Tecator, Hoganas, Sweden). Crude fiber, neutral detergent fiber, acid detergent fiber, and acid detergent lignin in diets were determined according to van Soest et al. (1991) using Foss Analytical FiberCap System (Foss Tecator, Sweden). Concentrations of rumen total volatile fatty acid (VFA) were determined by titrating the steam distillate of rumen fluid with $0.1 \mathrm{~N} \mathrm{NaOH}$. The titrated distillate was dried and then individual VFA concentrations were determined using gas chromatography (5890A, Hewlett Packard, Avondale, PA, USA). Concentration of rumen $\mathrm{NH}_{3}$ was determined by colorimetric method (Weatherburn, 1967).

In pre-infusion period of isotope dilution method, plasma free amino acids, $\mathrm{NH}_{3}$ and urea were determined using an automatic amino acid analyzer (JLC-500/V, JEOL, Akishima, Japan). Plasma concentrations of non-esterified fatty acid (NEFA) were determined enzymatically using a diagnostic kit (NEFA C, Wako Pure Chemicals, Osaka, Japan).

To determine the concentrations and enrichments of plasma glucose and Leu, plasma $\left[\mathrm{U}-{ }^{13} \mathrm{C}\right]$ glucose and isotope enrichments were measured by the procedure of Tserng and Kalhan (1983) with slight modifications as described previously by Sano et al. (1996). The enrichment of plasma $\left[\mathrm{U}-{ }^{13} \mathrm{C}\right]$ glucose was determined using the selected ion monitoring with gas chromatography mass spectrometry system (GC/MS) (QP-2010, Shimadzu, Kyoto, Japan). Concentrations of plasma glucose were determined enzymatically using the method described by Huggett and Nixon (1957). Plasma amino acids were separated and converted to N-methyl-N-t-butyl-dimethylsilyltrifluroacetamide (MTBSTFA; Funakoshi, PCC48920, Tokyo, Japan) derivatives according to the procedures of Calder and Smith (1988) as described previously (Sano et al., 2004). Isotopic enrichments of plasma $\left[1-{ }^{13} \mathrm{C}\right] \mathrm{Leu}$ and concentration of plasma Leu were measured by the selected ion monitoring using the GC/MS.

\section{Calculation}

Results were presented as mean values with standard error of the mean. For the isotope dilution methods, the TR of plasma glucose and Leu was calculated using the equation described by Tserng and Kalhan (1983) as follows:

$$
\mathrm{TR}=I \times(1 / \mathrm{E}-1)
$$

Where, $I$ is the infusion rate of $\left[\mathrm{U}-{ }^{13} \mathrm{C}\right]$ glucose and $[1-$ $\left.{ }^{13} \mathrm{C}\right]$ Leu isotopes and $\mathrm{E}$ is the plasma isotopic enrichments of $\left[\mathrm{U}-{ }^{13} \mathrm{C}\right]$ glucose and $\left[1-{ }^{13} \mathrm{C}\right]$ Leu during the steady state, respectively.

\section{Statistical analysis}

All data were statistically analyzed using analysis of variance with the MIXED procedure of SAS (1996). The least square means statement was used to test the effects of period and diet. Results were considered significant at the $\mathrm{p}<0.05$ level, and a tendency was defined as $0.05 \leq \mathrm{p}<0.10$. The repeated measures statement and the Tukey adjustment were used for the time course of changes and the significance level was $\mathrm{p}<0.05$.

\section{RESULTS AND DISCUSSION}

\section{Daily profile and nitrogen balance}

The sheep consumed the RSUM-diet more slowly than the MH-diet. The daily BW gain did not differ $(p=0.26)$ between the diets (Table 2). It was meant that no adverse effect was found on BW gain in sheep throughout the experiment for RSUM-diet. A similar trend was found in lambs fed urea treated rice straw supplemented with molasses (Hue et al., 2008). Dry matter intake was greater $(p=0.02)$ for the RSUM-diet compared to the MH-diet due to difference in feed allowance. The present result was supported by the findings of Singh et al. (1995). Estimated

Table 2. Dietary effects on body weight gain, dry matter intake, estimated metabolizable energy intake, nitrogen intake and nitrogen digestibility in sheep

\begin{tabular}{lcccc}
\hline Item & MH-diet & RSUM-diet & SEM & p-value \\
\hline No. of sheep & 4 & 4 & & \\
BW gain $(\mathrm{kg} / \mathrm{d})$ & 0.09 & 0.03 & 0.05 & 0.26 \\
$\mathrm{DM}$ intake $\left(\mathrm{g} / \mathrm{kg}^{0.75} / \mathrm{d}\right)$ & 54 & 59 & 2 & 0.02 \\
$\mathrm{ME}$ intake $\left(\mathrm{kcal}^{\mathrm{k}} / \mathrm{kg}^{0.75} / \mathrm{d}\right)$ & 99 & 92 & 2 & 0.21 \\
$\mathrm{~N}$ intake $\left(\mathrm{g} / \mathrm{kg}^{0.75} / \mathrm{d}\right)$ & 1.10 & 0.94 & 0.05 & 0.01 \\
$\mathrm{~N}$ in feces $\left(\mathrm{g} / \mathrm{kg}^{0.75} / \mathrm{d}\right)$ & 0.37 & 0.30 & 0.02 & 0.01 \\
$\mathrm{~N}$ in urine $\left(\mathrm{g} / \mathrm{kg}^{0.75} / \mathrm{d}\right)$ & 0.45 & 0.46 & 0.01 & 0.90 \\
$\mathrm{~N}$ retention $\left(\mathrm{g} / \mathrm{kg}^{0.75} / \mathrm{d}\right)$ & 0.28 & 0.18 & 0.04 & 0.03 \\
$\mathrm{~N}$ digestibility $(\%)$ & 67 & 67 & 1 & 0.57 \\
\hline
\end{tabular}

$\mathrm{MH}$, Mixed hay of orchardgrass and reed canarygrass; RSUM, Rice straw supplemented with urea and molasses; BW, body weight; DM, dry matter; $\mathrm{ME}$, metabolizable energy; $\mathrm{N}$, nitrogen.

Estimated according to NRC (1985) and NARO (2006). 
ME intake did not differ $(p=0.21)$ between diets. Nitrogen intake and $\mathrm{N}$ excretion through feces were lower $(\mathrm{p}=0.01)$ for the RSUM-diet than the MH-diet. Lower N intake for the RSUM-diet might be due to loss of some $\mathrm{N}$ through residue of rice straw. Nitrogen excretion through urine did not differ between diets and $\mathrm{N}$ retention was lower $(\mathrm{p}=0.03)$ for the RSUM-diet than the MH-diet. No significant difference $(\mathrm{p}=0.57)$ occurred in $\mathrm{N}$ digestibility between diets in the present study. Can et al. (2004) reported the lower $\mathrm{N}$ digestibility in lambs fed only wheat straw than wheat straw supplemented with urea and molasses. Similar results were obtained in our previous study (Alam et al., 2010). It can be said that $\mathrm{N}$ intake as well as $\mathrm{N}$ digestibility were improved in sheep fed RSUM-diet than rice straw only. This is probably be due to addition of urea and molasses to rice straw which supplies required $\mathrm{NH}_{3}$ and energy for microbial activities in the rumen of sheep.

\section{Rumen fermentation characteristics}

Rumen $\mathrm{pH}$ determined at $2 \mathrm{~h}$ after feeding did not differ $(\mathrm{p}=0.81)$ between dietary treatments (Table 3$)$. The $\mathrm{pH}$ values were within the normal range for both the diets. Similar rumen $\mathrm{pH}$ between diets was an indication of balance between the concentrations of VFA and $\mathrm{NH}_{3}$ in the rumen as described previously (Alam et al., 2010). The numerical values of rumen $\mathrm{pH}$ of the present findings were comparable with the data reported in sheep fed urea supplemented diet (Sano et al., 2009). Leng (1990) reported that the critical level of $\mathrm{NH}_{3}$ is between 2.9 and 14.7 $\mathrm{mmol} / \mathrm{L}$ of rumen liquor for promoting the rumen fermentation. In the present study rumen $\mathrm{NH}_{3}$ concentration was within the normal range for promoting the rumen fermentation. Concentration of rumen $\mathrm{NH}_{3}$ was higher $(\mathrm{p}=$ 0.03 ) for the RSUM-diet than the MH-diet in the present study. The higher rumen $\mathrm{NH}_{3}$ concentration for the RSUMdiet was likely due to the presence of urea and molasses, because the urea is rapidly hydrolyzed and provides $\mathrm{NH}_{3}$

Table 3. Dietary effects on rumen $\mathrm{pH}$, concentrations of rumen ammonia $\left(\mathrm{NH}_{3}\right)$ and volatile fatty acids (VFA) in sheep

\begin{tabular}{lcccc}
\hline Item & MH-diet & RSUM-diet & SEM & p-value \\
\hline No. of sheep & 4 & 4 & & \\
Rumen pH & 6.82 & 6.86 & 0.10 & 0.81 \\
$\mathrm{NH}_{3}(\mathrm{mmol} / \mathrm{L})$ & 4.56 & 7.06 & 1.06 & 0.03 \\
VFA (mmol/L) & & & & \\
$\quad$ Total & 79.5 & 88.4 & 6.4 & 0.09 \\
$\quad$ Acetic acid & 59.5 & 61.3 & 4.4 & 0.38 \\
$\quad$ Propionic acid & 13.7 & 20.9 & 2.6 & 0.01 \\
iso-Butyric acid & 0.7 & 0.3 & 0.1 & 0.01 \\
$\quad$ Butyric acid & 4.6 & 5.3 & 0.5 & 0.17 \\
$\quad$ iso-Valeric acid & 0.7 & 0.3 & 0.2 & 0.05 \\
$\quad$ Valeric acid & 0.5 & 0.3 & 0.1 & 0.34 \\
\hline
\end{tabular}

$\mathrm{MH}$, mixed hay of orchardgrass and reed canarygrass; RSUM, rice straw supplemented with urea and molasses; SEM, standard error of the mean. and molasses provides the required energy substrate for microbial activities in the rumen. This is in accordance with the results of Srinivas and Gupta (1997) and Jain et al. (2005), who reported that in ruminants, supplementation of urea and molasses to low quality roughage diets made better rumen environment for dietary carbohydrate fermentation through supplying adequate $\mathrm{NH}_{3}$ and energy for rumen microbial growth. Concentrations of rumen total VFA tended to be higher $(p=0.09)$ for the RSUM-diet than the $\mathrm{MH}$-diet. Acetate concentration in the rumen did not differ $(p=0.38)$ between diets, whereas propionate concentration was higher $(\mathrm{p}=0.01)$ for the RSUM-diet than the MH-diet. A tendency of higher rumen total VFA for the RSUM-diet has indicated well fermentation of dietary carbohydrate in the rumen. Similarly Jain et al. (2005) observed that rumen VFA concentrations were affected by urea, molasses and mineral granules supplementation with rice straw in goat kids. Propionate concentration in the rumen was affected by the readily fermentable carbohydrate in the diets (van Houtert, 1993). Higher concentration of ruminal propionate for the RSUM-diet was due to presence of molasses as a source of water soluble carbohydrate. Supplementation of molasses to rice straw might activate the microbes which produce propionate in the rumen. The present results were supported by Broderick and Radloff (2004), who mentioned that molasses supplementation to diets influenced the propionate concentration in the rumen.

\section{Blood metabolites}

Plasma free amino acid concentration is influenced by the several factors such as dietary types and frequency of feeding, protein degradation, microbial protein synthesis and amino acid absorption (Leng and Nolan, 1984; Alam et al., 2013). Plasma free amino acids determined at preinfusion of isotope dilution did not differ ( $p>0.10)$ between diets, except that lysine, glutamic acid and glutamine were higher $(\mathrm{p}<0.05)$ for the RSUM-diet compared to the MHdiet (Table 4). The observation might be due to adequate supply of $\mathrm{NH}_{3}$ and easily fermentable energy substrates for microbial protein synthesis for the RSUM-diet. Concentrations of plasma $\mathrm{NH}_{3}$ tended to be higher ( $\mathrm{p}=$ 0.07 ) for the RSUM-diet compared to the MH-diet, and plasma urea concentration did not differ $(p=0.18)$ between diets. Concentration of $\mathrm{NH}_{3}$ in plasma is positively associated with the production of $\mathrm{NH}_{3}$ in the rumen (Nolan and Leng, 1972; Milano and Lobley, 2001). A tendency of higher plasma $\mathrm{NH}_{3}$ concentration for the RSUM-diet might be reflected by rapid absorption of $\mathrm{NH}_{3}$ from the rumen. The present result is in accordance with the results by Sano et al. (2009), who suggested that when urea was supplemented to the basal diet, the postprandial plasma $\mathrm{NH}_{3}$ increased temporally because a large part of the $\mathrm{NH}_{3}$ produced from the supplemental urea in the rumen and 
Table 4. Dietary effects on plasma free amino acids, ammonia $\left(\mathrm{NH}_{3}\right)$, urea and non-esterified fatty acid (NEFA) concentrations in sheep

\begin{tabular}{|c|c|c|c|c|}
\hline Items & MH-diet & RSUM-diet & SEM & p-value \\
\hline No. of sheep & 4 & 4 & & \\
\hline \multicolumn{5}{|c|}{ Amino acids $(\mu \mathrm{mol} / \mathrm{L})$} \\
\hline Threonine & 194 & 163 & 41 & 0.07 \\
\hline Valine & 228 & 185 & 34 & 0.13 \\
\hline Methionine & 37 & 29 & 14 & 0.49 \\
\hline Iso-leucine & 92 & 74 & 16 & 0.26 \\
\hline Leucine & 100 & 85 & 20 & 0.38 \\
\hline Phenylalanine & 45 & 41 & 6 & 0.48 \\
\hline Histidine & 24 & 23 & 2 & 0.43 \\
\hline Lysine & 32 & 43 & 5 & 0.04 \\
\hline Aspartic acid & 14 & 12 & 2 & 0.11 \\
\hline Serine & 205 & 176 & 14 & 0.33 \\
\hline Asparagine & 66 & 70 & 11 & 0.93 \\
\hline Glutamic acid & 253 & 332 & 24 & 0.02 \\
\hline Glutamine & 84 & 121 & 21 & 0.01 \\
\hline Glycine & 610 & 583 & 44 & 0.11 \\
\hline Alanine & 183 & 197 & 18 & 0.09 \\
\hline Tyrosine & 58 & 63 & 11 & 0.39 \\
\hline Tryptophan & 149 & 136 & 25 & 0.41 \\
\hline Arginine & 131 & 101 & 15 & 0.06 \\
\hline Proline & 67 & 68 & 12 & 0.78 \\
\hline $\mathrm{NH}_{3}(\mu \mathrm{mol} / \mathrm{L})$ & 383 & 419 & 16 & 0.07 \\
\hline Urea $(\mathrm{mmol} / \mathrm{L})$ & 7.83 & 8.37 & 0.89 & 0.18 \\
\hline NEFA $(\mu \mathrm{Eq} / \mathrm{L})$ & 284 & 148 & 62 & 0.03 \\
\hline
\end{tabular}

$\mathrm{MH}$, mixed hay of orchardgrass and reed canarygrass; RSUM, rice straw supplemented with urea and molasses; SEM, standard error of the mean.

directly absorbed into portal blood. Concentration of plasma NEFA was lower $(p=0.03)$ for the RSUM-diet than the MH-diet. Plasma NEFA concentration is the indicator of energy status in ruminants (Fox et al., 1991), because plasma NEFA is mobilized to supply the metabolic needs of animal, primarily the need of energy. In the current study, lower plasma NEFA concentration for the RSUM-diet indicated its improved nutritional status due to nitrogenous substrate and soluble carbohydrate supplementation.

\section{Plasma glucose and leucine kinetics}

Plasma glucose concentration and $\left[\mathrm{U}^{-13} \mathrm{C}\right]$ glucose enrichment remained constant during the latter half of the isotope infusion (Figure 1), which indicated the steady state condition. Concentration of plasma glucose determined during the last $2 \mathrm{~h}$ continuous infusion of isotope dilution did not differ $(\mathrm{p}=0.51)$ between the RSUM-diet and the MH-diet (Table 5). The numerical values of plasma glucose concentration were similar with the data previously reported in sheep fed rice straw supplemented with corn starch as energy source (Zhang et al., 2009). In ruminants gluconeogenesis takes place mainly in liver and rates of plasma glucose turnover (TR) were influenced with several

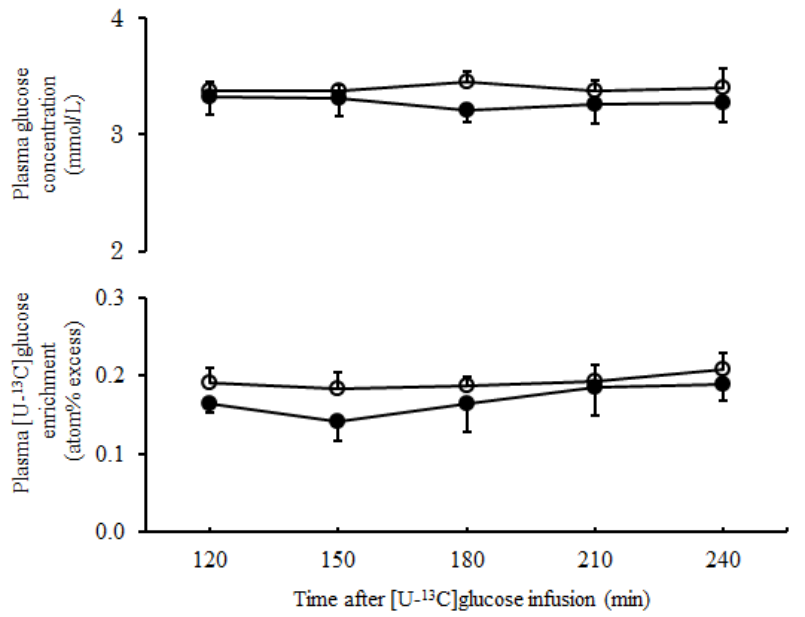

Figure 1. Time course changes in plasma glucose concentration and enrichment of $\left[\mathrm{U}_{-}{ }^{13} \mathrm{C}\right]$ glucose during 120 to $240 \mathrm{~min}$ of the primed-continuous infusion of $\left[\mathrm{U}^{13} \mathrm{C}\right]$ glucose in sheep $(\mathrm{n}=4)$ fed the RSUM-diet $(\bullet)$ and the MH-diet ( $\circ$ ) (Means \pm standard error of the mean).

factors such as the type of diet, energy intake and supply of gluconeogenic substrate to the liver (Ortigues-Marty et al., 2003; Sano and Fujita, 2006). In previous studies it was suggested that the precursor availability is an important factor in regulating gluconeogenesis (Schmidt and Keith, 1983; Oba and Allen, 2003). Plasma glucose TR in the present study did not differ $(\mathrm{p}=0.31)$ between the RSUMdiet and the $\mathrm{MH}$-diet, although the rumen propionate concentration, a major glucose precursor, was higher for the RSUM-diet. This is in accordance with Seal and Parker (1994), who reported that increasing supply of glucogenic substrates did not influence the plasma glucose TR in steers. Although the isotope dilution method was different, the numerical values of plasma glucose TR of the present findings were comparable to the data reported in sheep fed plantain herb (Al-Mamun et al., 2007).

Plasma Leu concentration and $\left[1-{ }^{13} \mathrm{C}\right] \mathrm{Leu}$ enrichment were stable during the latter half of the isotope infusion (Figure 2) which indicated the steady state condition. Concentration of plasma Leu determined during the last $2 \mathrm{~h}$

Table 5. Dietary effects on kinetics of plasma glucose and leucine (Leu) metabolism in sheep

\begin{tabular}{lcccc}
\hline Items & MH-diet & RSUM-diet & SEM & p-value \\
\hline No. of sheep & 4 & 4 & & \\
Glucose & & & & \\
$\quad$ Concentration $(\mathrm{mmol} / \mathrm{L})$ & 3.38 & 3.28 & 0.11 & 0.51 \\
$\quad \mathrm{TR}\left(\mathrm{mmol} / \mathrm{kg}^{0.75} / \mathrm{h}\right)$ & 1.43 & 1.52 & 0.18 & 0.31 \\
Leu & & & & \\
$\quad$ Concentration $(\mu \mathrm{mol} / \mathrm{L})$ & 93.4 & 77.3 & 6.6 & 0.11 \\
$\quad$ TR $\left(\mu \mathrm{mol} / \mathrm{kg}^{0.75} / \mathrm{h}\right)$ & 285 & 272 & 49 & 0.76 \\
\hline
\end{tabular}

$\mathrm{MH}$, mixed hay of orchardgrass and reed canarygrass; RSUM, rice straw supplemented with urea and molasses; SEM, standard error of the mean; $\mathrm{TR}$, turnover rate. 


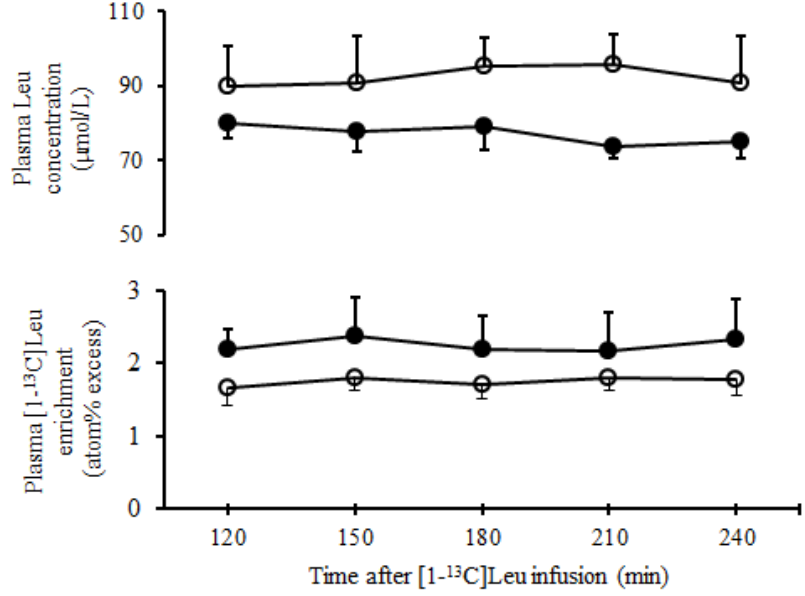

Figure 2. Time course changes of plasma leucine concentration and enrichment of $\left[1-{ }^{13} \mathrm{C}\right]$ Leu during 120 to $240 \mathrm{~min}$ of the primed-continuous infusion of $\left[1-{ }^{13} \mathrm{C}\right]$ Leu in sheep $(\mathrm{n}=4)$ fed the RSUM-diet $(\bullet)$ and the MH-diet (०) (Means \pm standard error of the mean). RSUM, rice straw supplemented with urea and molasses; $\mathrm{MH}$, mixed hay.

of the primed-continuous infusion did not differ $(p=0.11)$ between diets. In the present study, although $\mathrm{N}$ intake was lower for the RSUM-diet than the MH-diet, plasma LeuTR did not differ $(p=0.76)$ between diets. The present results were supported by Sano et al. (2009), who reported that supplementation of urea and soybean meal to roughagebased diets did not influence the plasma LeuTR in sheep. Moreover, numerical values of plasma LeuTR of the present findings were greater than the data previously found in sheep fed rice straw only (Alam et al., 2010), because the $\mathrm{N}$ and ME intake were also greater in sheep fed the RSUMdiet.

In conclusion, RSUM-diet showed improved performance than mixed hay on rumen fermentation characteristics and comparable performance to mixed hay on TR of plasma glucose and Leu in sheep. It can be suggested that rice straw supplemented with nitrogenous substrates in combination with soluble carbohydrate can be used for raising the livestock production as like as mixed hay.

\section{CONFLICT OF INTEREST}

We certify that there is no conflict of interest with any financial organization regarding the material discussed in the manuscript.

\section{REFERENCES}

Alam, M. K., Y. Ogata, Y. Sako, M. Al-Mamun, and H. Sano. 2010. Intermediary metabolism of plasma acetic acid, glucose and protein in sheep fed a rice straw-based diet. Asian Australas. J. Anim. Sci. 23:1333-1339.
Alam, M. K., M. Sasaki, M. Al-Mamun, and H. Sano. 2013. Plasma acetate turnover rate and rumen fermentation characteristics in sheep fed rice straw supplemented with soybean meal. J. Anim. Sci. Adv. 3:65-73.

Al-Mamun, M., C. Tanaka, Y. Hanai, Y. Tamura, and H. Sano. 2007. Effects of plantain (Plantago lanceolata L.) herb and heat exposure on plasma glucose metabolism in sheep. Asian Australas. J. Anim. Sci. 20:894-899.

AOAC. 1995. Official Methods of Analysis, 16th edn. Association of Official Analytical Chemists, Arlington, VA, USA.

Broderick, G. A. and W. J. Radloff. 2004. Effect of molasses supplementation on the production of lactating dairy cows fed diets based on alfalfa and corn silage. J. Dairy Sci. 87:29973009.

Calder, A. G. and A. Smith. 1988. Stable isotope ratio analysis of leucine and ketoisocaproic acid in blood plasma by gas chromatography/mass spectrometry. Use of tertiary butyldimethylsilyl derivatives. Rapid Commun. Mass Spectrum. 2:14-16.

Can, A., N. Denek, and K. Yazgan. 2004. Effect of urea and molasses supplementation on nutrient intake and digestibility of sheep fed with straw. J. Anim. Vet. Adv. 3:466-469.

Fox, M. T., D. Gerrelli, S. R. Pitt, and D. E. Jacobs. 1991. The relationship between appetite and plasma non-esterified fatty acid levels in housed calves. Vet. Res. Commun. 15:127-133.

Hue, K. T., D. T. T. Van, and I. Ledin. 2008. Effect of supplementing urea treated rice straw and molasses with different forage species on the performance of lambs. Small Rumin. Res. 78:134-143.

Huggett, A. G. and D. A. Nixon. 1957. Enzymatic determination of blood glucose. Biochem. J. 66:12.

Jain, N., S. P. Tiwari, and P. Singh. 2005. Effect of urea molasses mineral granules on rumen fermentation pattern and blood biochemical constituents in goat kids fed sola (Aeschonomene indica L.) grass-based diet. J. Vet. Arhiv. 75:521-530.

Leng, R. A. 1990. Factors affecting the utilization of 'poor-quality' forages by ruminants particularly under tropical conditions. Nutr. Res. Rev. 3:277-303.

Leng, R. A. and J. V. Nolan. 1984. Protein nutrition of the lactating dairy cow. J. Dairy Sci. 67:1072-1089.

Milano, G. D. and G. E. Lobley. 2001. Liver nitrogen movements during short-term infusion of high levels of ammonia into the mesenteric vein of sheep. Br. J. Nutr. 86:507-513.

National Agriculture and Food Research Organization. 2006. Japanese feeding standard for dairy cattle. Japan Livestock Industry Association, Tokyo, Japan.

National Research Council. 1985. Nutrient Requirements of Sheep 6th Ed. National Academy Press, Washington, DC, USA.

Nolan, J. V. and R. A. Leng. 1972. Dynamic aspects of ammonia and urea metabolism in sheep. Br. J. Nutr. 27:177-194.

Oba, M. and M. S. Allen. 2003. Extent of hypophagia caused by propionate infusion is related to plasma glucose concentration in lactating dairy cows. J. Nutr. 133:1105-1112.

Ortigues-Marty, I., J. Vernet, and L. Majdoub. 2003. Whole body glucose turnover in growing and non-productive adult ruminants: meta-analysis and review. J. Reprod. Nutr. Dev. 43:371-383.

Rooke, J. A. and D. G. Armstrong. 1989. The importance of the form of nitrogen on microbial protein synthesis in the rumen of 
cattle receiving grass silage and continuous intrarumen infusions of sucrose. Br. J. Nutr. 61:113-121.

Sano, H. and T. Fujita. 2006. Effect of supplemental calcium propionate on insulin action to blood glucose metabolism in adult sheep. Reprod. Nutr. Dev. 46:9-18.

Sano, H., T. Fujita, M. Murakami, and A. Shiga. 1996. Stimulative effect of epinephrine on glucose production and utilization rates in sheep using a stable isotope. Domest. Anim. Endocrinol. 13:445-451.

Sano, H., M. Kajita, and T. Fujita. 2004. Effect of dietary protein intake on plasma leucine flux, protein synthesis, and degradation in sheep. Comp. Biochem. Physiol. B. 139:163168.

Sano, H., S. Shibasaki, and H. Sawada. 2009. The effect of the source of nitrogen supplementation on nitrogen balance, rates of plasma leucine turnover, protein synthesis and degradation in sheep. Arch. Anim. Nutr. 63:401-412.

Sarnklong, C., J. W. Cone, W. Pellikaan, and W. H. Hendriks. 2010. Utilization of rice straw and different treatments to improve its feed value for ruminants: A Review. Asian Australas. J. Anim. Sci. 23:680-692.

Schmidt, S. P. and R. K. Keith. 1983. Effects of diet and energy intake on kinetics of glucose metabolism in steers. J. Nutr. 113:2155-2163

Seal, C. J. and D. S. Parker. 1994. Effect of intraruminal propionic acid infusion on metabolism of mesenteric- and portal-drained viscera in growing steers fed a forage diet: I. Volatile fatty acids, glucose, and lactate. J. Anim. Sci. 72:1325-1334.

Singh, G. P., B. N. Gupta, and M. Madhu. 1995. Effect of supplementation urea molasses mineral licks to straw diet on dry matter intake, volatile fatty acids and methane production. Indian J. Dairy Sci. 48:290-294.

Srinivas, B. and B. N. Gupta. 1997. Rumen fermentation, bacterial and total volatile fatty acid (TVFA) production rates in cattle fed on urea-molasses-mineral block licks supplement. Anim. Feed Sci. Technol. 65:275-286.

SAS. 1996. SAS/STAT Software: Changes and Enhancements through Release 6.11. SAS Inst. Inc. Cary, NC, USA.
Tedeschi, L. O, M. J. Baker, D. J. Ketchen, and D. G. Fox. 2002. Performance of growing and finishing cattle supplemented with a slow-release urea product and urea. Can. J. Anim. Sci. 82:567-573.

Toppo, S., A. K. Verma, R. S. Dass, and U. R. Mehra. 1997. Nutrient utilization and rumen fermentation pattern in crossbred cattle fed different planes of nutrition supplemented with urea molasses mineral block. Anim. Feed Sci. Technol. 64:101-112.

Tserng, K. Y. and S. C. Kalhan. 1983. Calculation of substrate turnover rate in stable isotope tracer studies. Am. J. Physiol. 245:E308-E311.

Van Houtert, M. F. J. 1993. The production and metabolism of volatile fatty acids by ruminants fed roughages: A review. Anim. Feed Sci. Technol. 43:189-255.

van Soest, P. J., J. B. Robertson, and B. A. Lewis. 1991. Methods for dietary fiber, neutral detergent fiber, and nonstarch polysaccharides in relation to animal nutrition. J. Dairy Sci. 74:3583-3597.

Wanapat, M., S. Polyrach, K. Boonnop, C. Mapato, and A. Cherdthong. 2009. Effect of treating rice straw with urea and calcium hydroxide upon intake, digestibility, rumen fermentation and milk yield of dairy cows. Livest. Sci. 125:238-243.

Weatherburn, M. W. 1967. Phenol-hypochlorite reaction for determination of ammonia. Anal. Chem. 39:971-974.

Wu, Y., W. Hu, and J. Liu. 2005. Effects of supplementary ureaminerals lick block on the kinetics of fibre digestion, nutrient digestibility and nitrogen utilization of low quality roughages. J. Zhejiang Univ. Sci. 8:793-797.

Zhang, X. D., W. J. Chen, C. Y. Li, and J. X. Liu. 2009. Effects of protein-free energy supplementation on blood metabolites, insulin and hepatic PEPCK gene expression in growing lambs offered rice straw-based diet. Czech J. Anim. Sci. 54:481-489.

Zinn, R. A., R. Barrajas, M. Montano, and R. A. Ware. 2003. Influence of dietary urea level on digestive function and growth performance of cattle fed steam-flaked barley-based finishing diets. J. Anim. Sci. 81:2383-2389. 